Research paper

\title{
New insights into the alkoxycarbonylation of propargyl alcohol
}

\author{
A. Scrivanti*, V. Beghetto, M. Bertoldini \\ Dipartimento di Scienze Molecolari e Nanosistemi, Università Ca' Foscari Venezia, Via Torino 155, I-30172 Mestre, Italy
}

\section{A R T I C L E I N F O}

\section{Article history:}

Received 3 August 2017

Received in revised form

25 September 2017

Accepted 27 September 2017

\section{Keywords:}

Alkyne carbonylation

Propargyl alcohol

Methyl 2-(hydroxymethyl)acrylate

Palladium

Diphenyl-(6-methyl-pyridin-2-

yl)phosphine

\begin{abstract}
A B S T R A C T
The challenging carbonylation of propargyl alcohol is effectively catalyzed by $\mathrm{Pd}(\mathrm{OAc})_{2}$ in combination with diphenyl-(6-methyl-pyridin-2-yl)phosphine and methanesulfonic acid. In dichloroethane at 20-50 ${ }^{\circ} \mathrm{C}$, the reaction affords with almost complete regioselectivity alkyl 2-(hydroxymethyl)acrylates. Turnover frequency numbers (TOF) of up to $450 \mathrm{~h}^{-1}$ can be achieved working at $50{ }^{\circ} \mathrm{C}$, while a maximum turnover number (TON) of about 730 is obtained at $30^{\circ} \mathrm{C}$. The catalyst longevity is limited because the carbonylation product reacts with the phosphorus atom of the ligand to give a quaternary phosphonium salt. This reaction leads to deactivation of the catalyst and eventually to palladium black formation.
\end{abstract}

(c) 2017 Elsevier B.V. All rights reserved.

\section{Introduction}

The transition-metal catalyzed hydroxy- or alkoxycarbonylation of alkynes continues to attract considerable attention from academia and industry as confirmed by the numerous reviews available on the subject [1-6].

In particular, earlier studies on the transition-metal catalyzed alkoxycarbonylation of propargyl alcohol (see Scheme 1) and its derivatives can be traced back to 1950s [7-9], when pioneering experiments were carried out employing $\mathrm{Ni}(\mathrm{CO})_{4}$ either in stoichiometric or in catalytic fashion [10-15].

The reaction revealed to be very challenging requiring harsh conditions and generally affording complex mixtures from which pure products can be separated only with considerable difficulty.

At the end of the 1960s, Tsuji first employed palladium species, namely $\mathrm{PdCl}_{2}$ and $\mathrm{Pd} / \mathrm{C}$, promoted by hydrochloric acid as the catalysts $[16,17]$. Under quite severe conditions $\left(\mathrm{T}=100^{\circ} \mathrm{C}, \mathrm{P}(\mathrm{CO})=100 \mathrm{~atm}\right)$, methoxycarbonylation of propargyl alcohol was found to afford mixtures of 2-methoxymethylacrylate (Ia), dimethylitaconate (II), and trimethylaconitate (III) (Scheme 2).

In terms of control of the chemo- and regioselectivity the best results were obtained by Watanabe and co-workers employing $\left[\mathrm{PtH}\left(\mathrm{SnCl}_{3}\right)\left(\mathrm{PPh}_{3}\right)_{2}\right.$ [18]. In ethanol under quite harsh conditions these authors obtained with almost complete selectivity ethyl 2(hydroxymethyl)acrylate, albeit with a turnover number of 68 .

\footnotetext{
* Corresponding author.

E-mail address: scrivant@unive.it (A. Scrivanti).
}

More recently Williams reinvestigated the reaction [19] and suggested that the low reactivity and selectivity obtained are likely due to chelation of the triple bond and the oxygen atom of the propargyl alcohol to the catalyst metal centre.

Summing up it appears that about seventy years after the first attempts, the alkoxycarbonylation of propargyl alcohol is still an unsolved problem, even if the reaction represents an appealing, atom economical entry to 2-(hydroxymethyl)acrylates ( 1 in Scheme 1) which are useful building blocks for the synthesis of natural products [20,21], biologically active compounds [22,23]; and polymers [24-27].

At the beginning of the 1990s E. Drent and co-workers at Shell [28-30] disclosed an alkyne carbonylation catalytic system composed by $\mathrm{Pd}(\mathrm{OAc})_{2}$, a chelating P-N ligand containing a pyridylphosphine moiety and a strong, non-coordinating acid such as $\mathrm{CH}_{3} \mathrm{SO}_{3} \mathrm{H}$. This catalyst displays outstanding activities being able to furnish TOF as high as $40000 \mathrm{~h}^{-1}$ in methoxycarbonylation of propyne. Even more remarkable are the chemoselectivity and the regioselectivity of this system. As a matter of fact, double carbonylation is never observed and regioselectivity towards methyl methacrylate of up to $99.95 \%$ were obtained by Drent and coworkers. These, so far unsurpassed performances, are attributable to the unusual catalytic mechanism which according to experimental [31] and theoretical studies [32,33] entails as the key step the transfer of a proton from the pyridyl nitrogen of phosphine ligand to the terminal carbon atom of the substrate to give a $\sigma$-vinyl intermediate. According to these considerations, in particular spurred by the fact that double carbonylation is never observed, we deemed it interesting to investigate the alkoxycarbonylation of propargyl 


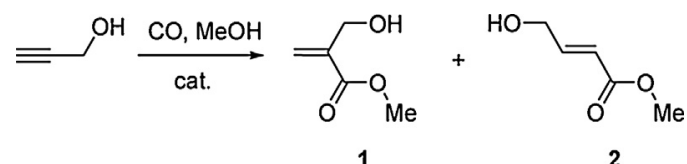

Scheme 1. Products expected in propargyl alcohol alkoxycarbonylation.

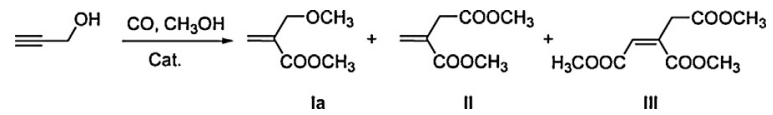

Scheme 2. Esters obtained in propargyl alcohol carbonylation by Tsuji.

alcohol in the presence of Drent's catalyst. In fact, to the best of our knowledge, Drent's catalyst has never been applied to the synthesis of 2-hydroxymethylacrylates, while there are only two papers [28,34], one of which by Drent himself, dealing with its application in intramolecular cyclocarbonylation of alkynols.

\section{Experimental}

\subsection{Materials}

All the operations were carried out under argon in Schlenktype glassware. Propargyl alcohol (Sigma-Aldrich) was distilled before use. Methanol (Sigma-Aldrich) was distilled from magnesium. Amylene stabilized dichloromethane (Sigma-Aldrich) was distilled from $\mathrm{CaH}_{2}$, while 1,2-dichloroethane (SigmaAldrich) and methanesulfonic acid (Sigma-Aldrich) were used as received. $\mathrm{Pd}(\mathrm{OAc})_{2}$ was purchased from Engelhard Industries. High purity CO was obtained by SIAD. Diphenyl-(pyrid-2-yl)phosphine and diphenyl-(6-methyl-pyrid-2-yl)phosphine were synthesized according to a literature method [35].

Methyl 2-(hydroxymethyl)acrylate (1) [36], methyl 2-(methoxymethyl)acrylate (1a) [37], and methyl (E)-4hydroxybut-2-enoate (2) [38] were characterized by recording their GC-MS and NMR spectra which were found in agreement with the literature data.

\subsection{Instrumentation}

${ }^{1} \mathrm{H},{ }^{31} \mathrm{P}$ and ${ }^{13} \mathrm{C}$ NMR spectra were registered in $\mathrm{CDCl}_{3}$ solutions on a Bruker AVANCE 300 spectrometer operating at 300.11, 121.43 and $75.44 \mathrm{MHz}$, respectively. GLC analyses were performed on an Agilent 6850 gas chromatograph; GC-MS analyses were performed on a HP 5890 series II gas chromatograph interfaced to a HP 5971 quadrupole mass-detector. ESI-MS analyses were performed using a Finnigan LCQ-Duo ion-trap instrument, operating in positive ion mode (sheath gas $\mathrm{N}_{2}$, source voltage $4.0 \mathrm{kV}$, capillary voltage $21 \mathrm{~V}$, capillary temperature $200^{\circ} \mathrm{C}$ ).

\subsection{Carbonylation experiments}

The carbonylation experiments were carried out in a magnetically stirred stainless steel autoclave (total volume about $150 \mathrm{~mL}$ ) connected to a thermostatic bath (Haake) in order to maintain the reaction temperature constant within $\pm 1^{\circ} \mathrm{C}$.

As an example, the experimental details for entry 4 of Table 3 are reported: under inert atmosphere, a Schlenk flask containing a small stirring bar was charged with $4.0 \mathrm{~mL}$ of 1,2-dichloroethane, $1.0 \mathrm{~mL}$ of methanol, $84.0 \mathrm{mg}(0.30 \mathrm{mmol})$ of diphenyl-(6-methylpyrid-2-yl)phosphine, $2.2 \mathrm{mg}(0.01 \mathrm{mmol})$ of $\mathrm{Pd}(\mathrm{OAc})_{2}, 580 \mu \mathrm{L}$ (560 mg, $10.0 \mathrm{mmol}$ ) of propargyl alcohol, and finally $19 \mu \mathrm{L}(28 \mathrm{mg}$, $0.30 \mathrm{mmol}$ ) of methanesulfonic acid.

The resulting yellow-orange solution was transferred via cannula into the autoclave. Then the reactor was pressurized with

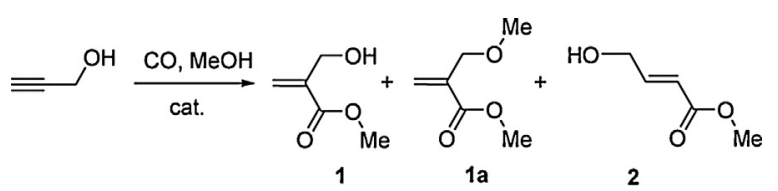

Cat.: $\mathrm{Pd}(\mathrm{OAc})_{2} /$ Phoshine/ $\mathrm{CH}_{3} \mathrm{SO}_{3} \mathrm{H}$

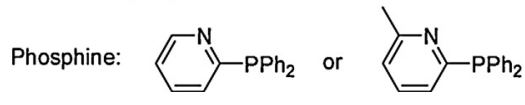

Scheme 3. General scheme for the methoxycarbonylation of propargyl alcohol.

$30 \mathrm{~atm}$ of $\mathrm{CO}$ and heated at $30^{\circ} \mathrm{C}$. After $2 \mathrm{~h}$ the autoclave was cooled at r.t., the residual gas carefully vented off, and the reaction mixture analyzed by GLC.

\subsection{Phosponium salts isolation}

At the end of a carbonylation experiment, the reaction crude was paper filtered to remove palladium black and then the filtrate was taken to dryness under high vacuum to give a brown oily residue. To this latter $5 \mathrm{~mL}$ of diethyl ether were added and the resulting two immiscible phases stirred with a small magnetic bar. After a few minutes, the oily residue tends to become a solid. The supernatant ether phase is carefully decanted and replaced with a fresh aliquot of diethylether. The whole procedure is repeated a few times until a yellow solid is obtained in about 55-65\% yield.

(2-(methyl carboxylate)-allyl)(pyridyl-2-)diphenylphosphonium methanesulfonate (3a).

${ }^{1} \mathrm{H}$ NMR $\left(298 \mathrm{~K} \mathrm{CDCl}_{3}\right) \delta: 8.84(\mathrm{~d}, 1 \mathrm{H}, J=4.0 \mathrm{~Hz}, \mathrm{Py}), 8.1-7.94$ ( $\mathrm{m}, 2 \mathrm{H}, \mathrm{Py}$ ) 7.8-7.4 (overlapping $\mathrm{m}, 11 \mathrm{H}, \mathrm{Py}$ and $\mathrm{Ph}$ ), $6.37(\mathrm{~d}, 1 \mathrm{H}$, $\left.J_{\mathrm{H}-\mathrm{P}}=5.0 \mathrm{~Hz},=\mathrm{CHH}\right), 6.16\left(\mathrm{~d}, 1 \mathrm{H}, J_{\mathrm{H}-\mathrm{P}}=5.0 \mathrm{~Hz},=\mathrm{CHH}\right), 4.72(\mathrm{~d}, 1 \mathrm{H}$, $\left.J_{\mathrm{H}-\mathrm{P}}=15.5 \mathrm{~Hz}, \mathrm{P}-\mathrm{CH}_{2}\right), 3.29\left(\mathrm{~s}, 3 \mathrm{H}, \mathrm{OCH}_{3}\right), 2.61\left(\mathrm{~s}, 3 \mathrm{H}, \mathrm{CH}_{3} \mathrm{SO}_{3}\right)$.

${ }^{31} \mathrm{P}$ NMR $\left(298 \mathrm{~K}, \mathrm{CDCl}_{3}\right) \delta: 17.6(\mathrm{~s})$.

${ }^{13} \mathrm{C} \mathrm{NMR}\left(298 \mathrm{~K} \mathrm{CDCl}_{3}\right) \delta: 165.5\left(\mathrm{~d}, 1 \mathrm{C}, J_{\mathrm{C}-\mathrm{P}}=2.2 \mathrm{~Hz}, \mathrm{C}=\mathrm{O}\right), 151.7$ (d, 1C, JC-P $=19.4 \mathrm{~Hz}, \mathrm{Py}-\mathrm{C} 2), 144.2\left(\mathrm{~d}, 1 \mathrm{C}, J_{\mathrm{C}-\mathrm{P}}=115.9 \mathrm{~Hz}, \mathrm{Py}-\mathrm{C} 6\right)$, $138.6\left(\mathrm{~d}, 1 \mathrm{C}, J_{\mathrm{C}-\mathrm{P}}=10.2 \mathrm{~Hz}, \mathrm{Py}-\mathrm{C} 4\right), 135.2\left(\mathrm{~d}, 1 \mathrm{C}, J_{\mathrm{C}-\mathrm{P}}=2.9 \mathrm{~Hz}, \mathrm{Ph}-\mathrm{p}\right)$, $134.3\left(\mathrm{~d}, 2 \mathrm{C}, J_{\mathrm{C}-\mathrm{P}}=9.6 \mathrm{~Hz}, \mathrm{Ph}-\mathrm{m}\right), 133.7$ (d, 1C, $J_{\mathrm{C}-\mathrm{P}}=9.7 \mathrm{~Hz}$, allyl$\left.\mathrm{CH}_{2}\right), 131.9$ (d, 1C, $\left.J_{\mathrm{C}-\mathrm{P}}=24.1 \mathrm{~Hz}, \mathrm{Py}-\mathrm{C} 5\right), 130.2\left(\mathrm{~d}, 2 \mathrm{C}, J_{\mathrm{C}-\mathrm{P}}=12.6 \mathrm{~Hz}\right.$, $\mathrm{Ph}-0), 128.3\left(J_{\mathrm{C}-\mathrm{P}}=3.4 \mathrm{~Hz}, \mathrm{Py}-\mathrm{C} 3\right), 127.8\left(\mathrm{~d}, 1 \mathrm{C}, J_{\mathrm{C}-\mathrm{P}}=9.6 \mathrm{~Hz}\right.$, quaternary allyl-C) $116.9\left(\mathrm{~d}, 1 \mathrm{C}, J_{\mathrm{C}-\mathrm{P}}=84.9 \mathrm{~Hz}\right.$, Ph-ipso), $52.3\left(\mathrm{~s}, 1 \mathrm{C}, \mathrm{OCH}_{3}\right)$, 39.4 (s, 1C, $\mathrm{CH}_{3} \mathrm{SO}_{3}$ ), 24.9 (d, 1C, JC-P $=50.3 \mathrm{~Hz}, \mathrm{P}_{-} \mathrm{CH}_{2}$ ).

ESI-MS (m/z): 362.11 (100\%), calcd. for $\mathrm{C}_{22} \mathrm{H}_{21} \mathrm{NO}_{2} \mathrm{P}^{+}: 362.13$.

(2-(methyl carboxylate)-allyl)(6-methyl-pyrid-2yl)diphenylphosphonium methanesulfonate (3b).

${ }^{1} \mathrm{H}$ NMR $\left(298 \mathrm{~K}_{,} \mathrm{CDCl}_{3}\right) \delta:$ 8.1-7.4 (overlapping $\mathrm{m}, 13 \mathrm{H}$, arom.), $6.47\left(\mathrm{~d}, 1 \mathrm{H}, J_{\mathrm{H}-\mathrm{P}}=5.1 \mathrm{~Hz},=\mathrm{CHH}\right), 6.34\left(\mathrm{~d}, 1 \mathrm{H}, J_{\mathrm{H}-\mathrm{P}}=5.4 \mathrm{~Hz},=\mathrm{CHH}\right)$, $4.87\left(\mathrm{~d}, 2 \mathrm{H}, J_{\mathrm{H}-\mathrm{P}}=15.6 \mathrm{~Hz}, \mathrm{P}-\mathrm{CH}_{2}\right), 3.36\left(\mathrm{~s}, 3 \mathrm{H}, \mathrm{OCH}_{3}\right), 2.74(\mathrm{~s}, 3 \mathrm{H}$, $\left.\mathrm{Py}-\mathrm{CH}_{3}\right), 2.63\left(\mathrm{~s}, 3 \mathrm{H}, \mathrm{CH}_{3} \mathrm{SO}_{3}\right)$.

${ }^{31} \mathrm{P}$ NMR $\left(298 \mathrm{~K}, \mathrm{CDCl}_{3}\right) \delta: 17.1(\mathrm{~s})$.

${ }^{13} \mathrm{C} \mathrm{NMR}\left(298 \mathrm{~K} \mathrm{CDCl}_{3}\right) \delta: 165.3\left(\mathrm{~d}, 1 \mathrm{C}, J_{\mathrm{C}-\mathrm{P}}=2.3 \mathrm{~Hz}, \mathrm{C}=0\right), 161.5$ $\left(\mathrm{d}, 1 \mathrm{C}, J_{\mathrm{C}-\mathrm{P}}=21.4 \mathrm{~Hz}, \mathrm{Py}-\mathrm{C} 2\right), 142.7\left(\mathrm{~d}, 1 \mathrm{C}, J_{\mathrm{C}-\mathrm{P}}=113.7 \mathrm{~Hz}, \mathrm{Py}-\mathrm{C} 6\right)$, 138.3 (d, 1C, JC-P $=10.7 \mathrm{~Hz}, \mathrm{Py}-\mathrm{C} 3), 135.1$ (d, 1C, JC-P $=3.0 \mathrm{~Hz}, \mathrm{Ph}-$ p) $134.1\left(\mathrm{~d}, 1 \mathrm{C}, J_{\mathrm{C}-\mathrm{P}}=9.5 \mathrm{~Hz}\right.$, allyl-CH 2$), 134.0\left(\mathrm{~d}, 2 \mathrm{C}, J_{\mathrm{C}-\mathrm{P}}=9.5 \mathrm{~Hz}\right.$, $\mathrm{Ph}-\mathrm{m}), 130.1$ (d, 1C, $\left.J_{\mathrm{C}-\mathrm{P}}=12.6 \mathrm{~Hz}, \mathrm{Ph}-0\right) 128.7$ (d, 1C, $J_{\mathrm{C}-\mathrm{P}}=24.0 \mathrm{~Hz}$ ), 128.2 (d, 1C, $\left.J_{\mathrm{C}-\mathrm{P}}=3.5 \mathrm{~Hz}, \mathrm{Py}-\mathrm{C} 4\right), 127.9$ (d, 1C, $J_{\mathrm{C}-\mathrm{P}}=9.5 \mathrm{~Hz}$, quaternary allyl-C), $116.6\left(\mathrm{~d}, 1 \mathrm{C}, J_{\mathrm{C}-\mathrm{P}}=84.4 \mathrm{~Hz}, \mathrm{Ph}-\mathrm{ipso}\right), 52.2\left(\mathrm{~s}, 1 \mathrm{C}, \mathrm{OCH}_{3}\right)$, $39.2\left(\mathrm{~s}, 1 \mathrm{C}, \mathrm{CH}_{3} \mathrm{SO}_{3}\right), 24.3$ (s, 1C, Py-CH $), 24.9$ (d, 1C, JC-P $=51.7 \mathrm{~Hz}$, $\left.\mathrm{P}-\mathrm{CH}_{2}\right)$

ESI-MS (m/z): 376.12 (100\%), calcd. for $\mathrm{C}_{23} \mathrm{H}_{23} \mathrm{NO}_{2} \mathrm{P}^{+}: 376.15$.

\section{Results and discussion}

Preliminary carbonylation experiments (see Scheme 3 and Table 1) were carried out under the conditions most usually adopted when using Drent's catalytic system [28-30]. 
Table 1

Influence of the temperature and the catalyst composition on the methoxycarbonylation of propargyl alcohol.

\begin{tabular}{|c|c|c|c|c|c|c|c|c|c|c|}
\hline \multirow[t]{2}{*}{ Entry } & \multirow[t]{2}{*}{ Sub./Pd } & \multirow[t]{2}{*}{$\mathrm{Pd} / \mathrm{P} / \mathrm{H}^{+}$} & \multirow[t]{2}{*}{$\mathrm{T}\left({ }^{\circ} \mathrm{C}\right)$} & \multirow[t]{2}{*}{$t(h)$} & \multirow[t]{2}{*}{ Conv.\%a } & \multirow[t]{2}{*}{$\Sigma_{\mathrm{TON}}$} & \multicolumn{4}{|c|}{ Product composition $^{\mathrm{a}}$} \\
\hline & & & & & & & $1(\%)$ & $1 \mathrm{a}(\%)$ & $2(\%)$ & $\overline{b: n^{b}}$ \\
\hline 1 & 250 & $1 / 20 / 20$ & 60 & 3 & 84 & 210 & 85.6 & 8.5 & 5.9 & $94: 6$ \\
\hline 2 & 250 & $1 / 20 / 20$ & 60 & 20 & 85 & 212 & 21.6 & 72.2 & 6.1 & $94: 6$ \\
\hline 3 & 500 & $1 / 20 / 20$ & 60 & 3 & 40 & 200 & 76.1 & 18.8 & 5.1 & $95: 5$ \\
\hline 4 & 500 & $1 / 30 / 30$ & 60 & 3 & 56 & 280 & 94.0 & 1.8 & 4.2 & $96: 4$ \\
\hline 5 & 500 & $1 / 30 / 30$ & 70 & 3 & 55 & 275 & 92.3 & 3.6 & 4.1 & $96: 4$ \\
\hline 6 & 500 & $1 / 30 / 30$ & 50 & 3 & 51 & 255 & 94.7 & - & 5.3 & $95: 5$ \\
\hline 7 & 500 & $1 / 30 / 30$ & 50 & 18 & 65 & 325 & 91.5 & 3.8 & 4.7 & $95: 5$ \\
\hline 8 & 500 & $1 / 30 / 60$ & 50 & 3 & 61 & 305 & 23.8 & 71.4 & 4.8 & $95: 5$ \\
\hline 9 & 500 & $1 / 30 / 24$ & 50 & 3 & 50 & 250 & 95.2 & - & 4.8 & $95: 5$ \\
\hline
\end{tabular}

Reaction conditions: $\mathrm{Pd}(\mathrm{OAc})_{2}=0.02 \mathrm{mmol}$; phosphine ligand: $\mathrm{PyPPh}_{2}$; reaction solvent: $\mathrm{CH}_{3} \mathrm{OH}(10.0 \mathrm{~mL}) ; \mathrm{P}(\mathrm{CO})=30 \mathrm{~atm}$.

a by GLC.

b $\mathbf{b}: \mathbf{n}=$ branched to normal esters ratio: $(\mathbf{1}+\mathbf{1 a}): \mathbf{2}$.

Methanol was employed both as the co-reactant and as the solvent in order to minimize the formation of cyclic compounds, diphenyl-(2-pyridyl)phosphine $\left(\mathrm{PyPPh}_{2}\right)$ was employed as the ligand and the composition of the catalytic system was set at $\mathrm{Pd}(\mathrm{OAc})_{2} /$ phosphine/acid $=1 / 20 / 20$. The propargyl alcohol to palladium molar ratio was in the range 500-250:1 and the P(CO) was 30 bar.

In the first experiment (Entry 1 of Table 1 ) $84 \%$ substrate conversion was obtained by $3 \mathrm{~h}$ working at $60^{\circ} \mathrm{C}$. GLC, GC-MS and NMR reveal that the main reaction product is the synthetically useful methyl ester $\mathbf{1}$ which forms together a small amount of its methyl ether $\mathbf{1 a}(\mathbf{1}: \mathbf{1} \mathbf{a}-10: 1)$. Formation of $\mathbf{1 a}$ by reaction of $\mathbf{1}$ with methanol has been already reported to occur in the presence of palladium [39]. As usual, when using $\mathrm{PyPPh}_{2}$, small amounts of the linear regioisomer $\mathbf{2}$ are also formed (the $(\mathbf{1 + 1 a}): \mathbf{2}$ molar ratio is about 94:6). Finally, it is worth to note that significant amounts of palladium black were evident in the reaction crudes.

Aiming at obtaining complete substrate conversion, the reaction time was increased to $20 \mathrm{~h}$ (Entry 2 of Table 1 ). Nevertheless, substrate conversion remained almost identical to that obtained by $3 \mathrm{~h}$. Interestingly, in this experiment the main reaction product was found to be 1a substantiating that its formation occurs from $\mathbf{1}$ in a subsequent reaction (see below).

When the substrate to palladium molar ratio is increased to 500:1 (Entry 3 of Table 1), the substrate conversion decreases to $40 \%$, while the branched to linear isomer ratio does not change and the $\mathbf{1} / \mathbf{1}$ a ratio is about $4: 1$.

By comparing the results gathered in these three first runs, it appears that under these reaction conditions the maximum TON (turnover number: mol of products formed divided by mol of palladium) achievable is about 200, independently from the reaction time. This finding suggests that some side-reaction leading to deactivation of the catalyst takes place, hypothesis which is supported by the presence of metallic palladium in the reaction crudes.

In order to improve the catalyst longevity the phosphine and methanesulfonic to palladium molar ratios was increased to $30: 1$ (Entry 4 of Table 1 ). This catalyst composition led to $56 \%$ of substrate conversion $(\mathrm{TON}=280)$ by $3 \mathrm{~h}$. Slightly lower substrate conversions were obtained either carrying out the reaction at 70 (Entry 5) or at $50^{\circ} \mathrm{C}$ (Entry 6 ). We settled to carry out the following experiments at this latter temperature because no ether 1a was found among the reaction products. In particular, it is to point out that at this temperature the catalyst is still active after $3 \mathrm{~h}$ since on increasing the reaction time to $18 \mathrm{~h}$ the conversion increased up to $65 \%$ $(\mathrm{TON}=325)$. The branched to linear isomer ratio was always about 95:5, while a small amount of the ether 1a was also formed.

On changing the catalyst composition from $\mathrm{Pd}(\mathrm{OAc})_{2} /$ phosphine/acid $=1 / 30 / 30$ to $1 / 30 / 60$ the reaction rate can be further increased allowing to obtain $61 \%$ substrate conversion by $3 \mathrm{~h}$. However, this activity increase is obtained at the expense of a much larger formation of methyl ether 1a, which definitively appears promoted by methanesulfonic acid. Both these effects were confirmed by the experiment in Entry 9 of Table 1: the substrate conversion decreases and no 1a forms when the catalyst composition is set at $\mathrm{Pd}(\mathrm{OAc})_{2} /$ phosphine/acid $=1 / 30 / 24$.

The influence of the other reaction parameters can be highlighted by the data gathered in Table 2 . Halving the $\mathrm{MeOH}$ volume had no effect on the reaction course; furthermore, no significant effect was observed on changing the $\mathrm{CO}$ pressure in the $20-40 \mathrm{~atm}$ range (Entries 1-3). In order to assess the influence of the reaction solvent, the following reactions were carried out in mixtures prepared by adding $1.0 \mathrm{~mL}(5.27 \mathrm{mmol})$ of $\mathrm{MeOH}$ (as the alcoholic co-reagent) to $4.0 \mathrm{~mL}$ of the solvent under investigation. In $\mathrm{N}$-methylpyrrolidinone (NMP), a solvent which usually has a significant promoting effect in propyne carbonylation [28-30], no substrate conversion was observed (Entry 4). On the contrary, the use of a chlorinated solvent such as dichloromethane (DCM) has a beneficial effect on the reaction rate, so that propargyl alcohol conversion of up to $75 \%$ is obtained (Entry 5) still retaining the selectivity pattern obtained in neat methanol. This good result could be further improved by using 1,2-dichloroethane (DCE); in fact, in this solvent the alkyne conversion increases up to $85 \%$ giving 425 TONs (Entry 6). An experiment (Entry 7) carried out under the same conditions but with a reaction time of 1 h gave an alkyne conversion of $82 \%$, further demonstrating that while the catalyst is able to furnish very high turnover frequencies, its longevity is limited.

Looking for an higher catalytic efficiency we replaced diphenyl-(pyridin-2-yl)phosphine with diphenyl-(6-methylpyridin-2-yl)phosphine $\left(2 \mathrm{MePyPPh}_{2}\right)$ which usually allows to obtain higher activities and regioselectivies [28-30,40].

As expected, employing $2 \mathrm{MePyPPh}_{2}$, the efficiency of the system increases significantly: as a matter of fact not only a conversion of up to $89 \%(\mathrm{TON}=445)$ is achieved by $1 \mathrm{~h}$, but also the formation of the linear isomer is restricted to a level lower than 1\% (compare Entry 1 of Table 3 with Entry 7 of Table 2).

This exceedingly good result prompted us to carry out further experiments using an alkyne:Pd ratio of 1000:1 (Entries 2-5 in Table 3). Employing the reaction conditions of Entry 1, 43\% substrate conversion is obtained (Entry 2 ), but when the reaction time is doubled the substrate conversion increases allowing to get 650 TONs (Entry 3). Very interestingly, by lowering the reaction temperature at $30^{\circ} \mathrm{C}$ it is possible to further improve the catalyst efficiency obtaining $73 \%$ substrate conversion by $2 \mathrm{~h}$ (Entry 4 ). On the other hand, a decrease of the reaction temperature at $20^{\circ} \mathrm{C}$ does not allow for additional progress (Entry 5). The results of Entries 5 and 6 can be rationalized by taking into account that the substrate conversion actually results from the balance of two opposite reactions: the catalytic carbonylation and the path leading to catalyst deacti- 
Table 2

Influence of the CO pressure and of the solvent.

\begin{tabular}{|c|c|c|c|c|c|c|c|c|}
\hline \multirow[t]{2}{*}{ Entry } & \multirow[t]{2}{*}{ Solvent } & \multirow[t]{2}{*}{$\mathrm{P}(\mathrm{CO})(\mathrm{atm})$} & \multirow[t]{2}{*}{ Conv.\% ${ }^{\mathrm{a}}$} & \multirow[t]{2}{*}{$\Sigma_{\mathrm{TON}}$} & \multicolumn{4}{|c|}{ Product composition ${ }^{a}$} \\
\hline & & & & & $1(\%)$ & $1 \mathrm{a}(\%)$ & $2(\%)$ & $\mathrm{b}: \mathrm{n}^{\mathrm{b}}$ \\
\hline 1 & $\mathrm{MeOH}$ & 30 & 51 & 255 & 94.5 & - & 4.5 & $95: 5$ \\
\hline 2 & $\mathrm{MeOH}$ & 20 & 50 & 250 & 93.0 & 2.2 & 4.8 & $95: 5$ \\
\hline 3 & $\mathrm{MeOH}$ & 40 & 51 & 255 & 94.7 & - & 5.3 & $95: 5$ \\
\hline 4 & $\operatorname{NMP}^{\mathrm{c}}$ & 30 & 0 & 0 & - & - & - & - \\
\hline 5 & DCM $^{\mathrm{d}}$ & 30 & 75 & 375 & 95.2 & - & 4.8 & $95: 5$ \\
\hline 6 & $\mathrm{DCE}^{\mathrm{e}}$ & 30 & 85 & 425 & 95.3 & - & 4.7 & $95: 5$ \\
\hline 7 & $\operatorname{DCE}^{\mathrm{f}}$ & 30 & 82 & 410 & 95.0 & - & 5.0 & $95: 5$ \\
\hline
\end{tabular}

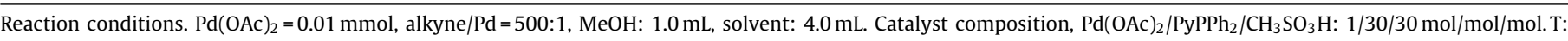
$50{ }^{\circ} \mathrm{C}$; reaction time: $3 \mathrm{~h}$.

a by GLC.

b $\mathbf{b : n = b r a n c h e d ~ t o ~ n o r m a l ~ e s t e r s ~ r a t i o : ~}(\mathbf{1}+\mathbf{1 a}): \mathbf{2}$.

c NMP: $N$-methylpyrrolidinone.

d DCM: dichloromethane.

e DCE: 1,2-dichloroethane.

${ }^{f}$ Reaction time: $1 \mathrm{~h}$.

Table 3

Propargyl alcohol carbonylation with $2 \mathrm{MePyPPh}_{2}$ as the ligand.

\begin{tabular}{|c|c|c|c|c|c|c|c|}
\hline \multirow[t]{2}{*}{ Entry } & \multirow[t]{2}{*}{ Sub./Pd } & \multirow[t]{2}{*}{$\mathrm{T}\left({ }^{\circ} \mathrm{C}\right)$} & \multirow[t]{2}{*}{$t(h)$} & \multirow[t]{2}{*}{ Conv. $\%^{a}$} & \multirow[t]{2}{*}{ TON } & \multicolumn{2}{|c|}{ Product composition (\%) ${ }^{a}$} \\
\hline & & & & & & 1 & 2 \\
\hline 1 & 500 & 50 & 1 & 89.0 & 445 & $>99 \%$ & traces \\
\hline 2 & 1000 & 50 & 1 & 43.3 & 433 & $>99 \%$ & traces \\
\hline 3 & 1000 & 50 & 2 & 65.0 & 650 & $>99 \%$ & traces \\
\hline 4 & 1000 & 30 & 2 & 73.0 & 730 & $>99 \%$ & traces \\
\hline 5 & 1000 & 20 & 2 & 73.0 & 730 & $>99 \%$ & traces \\
\hline
\end{tabular}

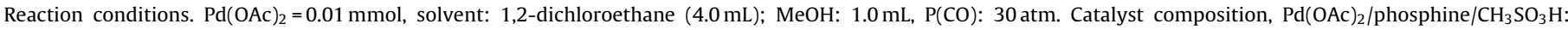
$1 / 30 / 30 \mathrm{~mol} / \mathrm{mol} / \mathrm{mol}$.

a By GLC.

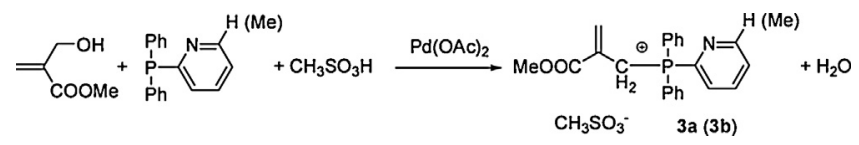

Scheme 4. Quaternization of the phosphorus ligands by reaction with methyl 2(hydroxymethyl)acrylate.

vation. It appears that on lowering the reaction temperature from 50 to $30^{\circ} \mathrm{C}$ the catalyst deactivation is slowed down more than the carbonylation.

Finally, we were intrigued to investigate into the reasons of the scarce longevity of the catalyst. In particular, formation of palladium black impressed us because during our past experiences on fine chemicals synthesis employing Drent's catalyst [41], we never faced this kind of problem.

At first, we recorded the ${ }^{31} \mathrm{P}\left\{{ }^{1} \mathrm{H}\right\}$ NMR spectrum of a reaction crude at the end of a catalytic run carried out employing $2 \mathrm{MePyPPh}_{2}$. Although some other small signals are also present, the spectrum essentially consists of a sharp singlet at $17.1 \delta$. This value of ${ }^{31} \mathrm{P}$ chemical shift suggests the presence of a quaternary phosphonium salt (as $\mathbf{3 b}$ in Scheme 4. In keeping with its cationic nature, this species was found to be soluble only in polar solvents (DCM, methanol) so that it was possible to recover it in almost pure form simply by taking to dryness the reaction crudes and washing the oily residues with diethyl ether. ESI-MS and NMR spectroscopy allowed to definitely assign to this species the structural formula $\mathbf{3 b}$ of Scheme 4. As a matter of fact, in the ${ }^{1} \mathrm{H}$ NMR spectrum of $\mathbf{3 b}$ the signal attributable to the allylic $\mathrm{CH}_{2}$ appears as a doublet centered at $4.87 \delta$. The resonance multiplicity is due to the coupling of the methylene protons with the phosphorus atom $\left(J_{\mathrm{H}-\mathrm{P}}=15.6 \mathrm{~Hz}\right)$, as confirmed by recording the relative ${ }^{1} \mathrm{H}$ $\left\{{ }^{31} \mathrm{P}\right\}$ spectrum. Also the vinylic hydrogens atoms which resonate at $6.37 \delta\left(J_{\mathrm{H}-\mathrm{P}}=5.0 \mathrm{~Hz}\right)$, and $6.16 \delta\left(J_{\mathrm{H}-\mathrm{P}}=5.0 \mathrm{~Hz}\right)$ display scalar coupling with the phosphorus atom. The structure of $\mathbf{3 b}$ was further demonstrated by recording its ${ }^{1} \mathrm{H}-{ }^{13} \mathrm{C}$ heterocorrelated 2D-NMR spectra (HMQC and $\mathrm{HMBC}$ ); the relevant data are reported in the Experimental part. Analogously, inspection of a crude recovered after a reaction carried out employing $\mathrm{PyPPh}_{2}$ revealed that the phosphine had been completely converted into the corresponding quaternary phosphonium salt $\mathbf{3 a}$. The occurrence of the reaction showed in Scheme 4 was independently confirmed by reacting methyl 2-hydroxymethylacrylate with $\mathrm{PyPPh}_{2}$ or $2 \mathrm{MePyPPh}_{2}$. It is noteworthy that: $\mathrm{i}$ ) in the absence of $\mathrm{CH}_{3} \mathrm{SO}_{3} \mathrm{H}$ the reaction does not proceed, and ii) the reaction is strongly accelerated when $\mathrm{Pd}(\mathrm{OAc})_{2}$ is present. Accordingly, it is likely that the formation of the phosphonium ion proceeds through the formation of a palladium coordinated allyl cation which then undergoes nucleophilic attack by the phosphine. In keeping with these findings, deactivation of the catalyst is to be attributed to the quaternization of the phosphine which then is no longer able to stabilize the catalytically active palladium species which finally decompose to give palladium metal. In this connection it is worth noting that the alkylation of triphenylphosphine by methyl 2-(chloromethyl)acrylate is known [42].

\section{Conclusions}

We have developed a quite efficient alkoxcarbonylation of propargyl alcohol allowing to obtain 2-(hydroxyl)acrylates with almost complete chemo- and regioselectivity. This result is to be attributed to the high efficiency of Drent's catalytic system which allows to carry out the reaction under very mild conditions. Limitations arise from the intrinsic high reactivity of the reaction product which reacting with the phosphine ligand shortens the catalyst lifetime. According to this finding, investigations on the alkoxycarbonylation of protected propargyl alcohols are in progress; further improvements could be achieved by replacing the Brønsted 
methanesulfonic acid with a suitable Lewis acid as found effective by Williams [43] in alkenes carbonylation.

\section{Acknowledgements}

This work was supported by the institutional funding of Ca' Foscari University Venice (ADIR 2015 and 2016). This research did not receive any specific grant from funding agencies in the public, commercial, or not-for-profit sectors. We are indebted with one of the anonymous reviewers who suggested investigating the influence of $\mathrm{Pd}(\mathrm{OAc})_{2}$ on phosphine quaternization.

\section{References}

[1] S. Quintero-Duque, K.M. Dyballa, I. Fleischer, Tetrahedron Lett. 56 (2015) 2634-2650.

[2] R. Chinchilla, C. Nájera, Chem. Rev. 114 (2014) 1783-1826.

[3] G. Kiss, Chem. Rev. 101 (2001) 3435-3456.

[4] A. Brennführer, H. Neumann, M. Beller, ChemCatChem 1 (2009) 28-41.

[5] R. Grigg, S.P. Mutton, Tetrahedron 66 (2010) 5515-5548.

[6] P. Kalck, M. Urrutigoïty, Inorg. Chim. Acta 431 (2015) 110-121.

[7] X.-F. Wu, H. Neumann, M. Beller, Chem. Rev. 113 (2013) 1-35.

8] J. Tsuji, T. Mandai, Angew. Chem. Int. Ed. Engl. 34 (1995) 2589-2612.

[9] I. Omae, Coord. Chem. Rev. 255 (2011) 139-160.

[10] E.R.H. Jones, T.Y. Shen, M.C. Whiting, J. Chem. Soc. 230 (1950) 230-236.

[11] G.P. Chiusoli, Chim. Ind. Milan 41 (1959) 513.

[12] R.W. Rosenthal, L.H. Schwartzman, J. Org. Chem. 24 (1959) 836-839.

[13] E.R.H. Jones, G.H. Whitham, M.C. Whiting, J. Chem. Soc. (1957) 4628-4633.

[14] P.J. Ashworth, G.H. Whitham, M.C. Whiting, J. Chem. Soc. (1957) 4633-4640.

[15] R.W. Rosenthal, L.H. Schwartzman, N.P. Greco, R. Proper, J. Org. Chem. 28 (1963) 2835-2838.

[16] T. Nogi, J. Tsuji, Tetrahedron 25 (1969) 4099-4108.

[17] J. Tsuji, Acc. Chem. Res. 2 (1969) 144-152.

[18] Y. Tsuji, T. Kondo, Y. Watanabe, J. Mol. Catal. 40 (1987) 295-304.

[19] B.F. Makume, T. Bredenkamp, D.B.G. Williams, ChemCatChem 6 (2014) 2801-2804

[20] M.T. Crimmins, D.L. Jacobs, Org. Lett. 11 (2009) 2695-2698.

[21] H. Suizu, D. Shigeoka, H. Aoyama, T. Yoshimitsu, Org. Lett. 17 (2015) 126-129.
[22] W. Erb, J.-M. Grassot, D. Linder, L. Neuville, J. Zhu, Angew. Chem. Int. Ed. 54 (2015) 1929-1932.

[23] R.L. Grange, J. Ziogas, A.J. North, J.A. Angus, C.H. Schiesser, Bioorg. Med. Chem. Lett. 18 (2008) 1241-1244.

[24] T. Sato, S. Hara, M. Sato, K. Ogawa, M. Adams, T. Usuki, Bioorg. Med. Chem. Lett. 25 (2015) 5504-5507.

[25] Y. Zhang, Z. Shen, D. Yang, C. Feng, J. Hu, G. Lu, X. Huang, Macromolecules 43 (2010) 117-125.

[26] Y. Li, Y. Zhang, D. Yang, J. Hu, G. Lu, X. Huang, J. Polym. Sci. Part A Polym. Chem. 48 (2010) 2084-2097.

[27] C. Peng, A. Joy, Macromolecules 47 (2014) 1258-1268.

[28] E. Drent, P. Arnoldy, J. Organomet. Chem. 455 (1993) 247-253.

[29] E. Drent, P. Arnoldy, P.H.M. Budzelaar, J. Organomet. Chem. 475 (1994) 57-63.

[30] J. Keijsper, P. Arnoldy, M.J. Doyle, E. Drent, Recl. Trav. Chim. Pays-Bas 115 (1996) 248-255.

[31] A. Scrivanti, V. Beghetto, E. Campagna, M. Zanato, U. Matteoli, Organometallics 17 (1998) 630-635.

[32] L. Crawford, D.J. Cole-Hamilton, E. Drent, M. Bühl, J. Chem. Eur. 20 (2014) $13923-13926$.

[33] L. Crawford, D.J. Cole-Hamilton, M. Bühl, Organometallics 34 (2015) 438-449.

[34] C.S. Consorti, G. Ebeling, J. Dupont, Tetrahedron Lett. 43 (2002) 753-755.

[35] D.M. Zink, M. Bächle, T. Baumann, M. Nieger, M. Kühn, C. Wang, W. Klopper, U. Monkowius, T. Hofbeck, H. Yersin, S. Bräse, Inorg. Chem. 52 (2013) 2292-2305.

[36] H.E. Bartrum, H. Adams, L. Caggiano, R.F.W. Jackson, Tetrahedron 64 (2008) 3701-3712.

[37] A.G. Mal'kina, R.N. Kudyakova, V.V. Nosyreva, A.V. Afonin, B.A. Trofimov, Russ J. Org. Chem. 38 (2002) 1088-1092.

[38] P.J. Ainsworth, D. Craig, J.C. Reader, A.M.Z. Slawin, A.J.P. White, D.J. Williams, Tetrahedron 51 (1995) 11601-11622.

[39] A. Hosokawa, T. Sugafuji, T. Yamanaka, S.-I. Murahashi, J. Organomet. Chem. 470 (1994) 253-255.

[40] T.A. Shuttleworth, A.M. Miles-Hobbs, P.G. Pringle, H.A. Sparkes, Dalton Trans. 46 (2017) 125-137.

[41] A. Scrivanti, M. Bertoldini, M. Aversa, A. Zancanaro, V. Beghetto, S. Paganelli, U. Matteoli, Tetrahedron 70 (2014) 5434-5438 (and references therein).

[42] R.D. Khachikyan, N.V. Tovmasyan, M.G. Indzhikyan, Russ. J. Gen. Chem. 77 (2007) 1034-1036.

[43] D.G. Williams, M.L. Shaw, M.J. Green, C.W. Holzapfel, Angew. Chem. Int. Ed. 47 (2008) 560-563. 